\title{
Do the Pacific Islands Still Need a Regional University
}

Eric Clem Groves, National University of Samoa

\section{Background of Higher Education in the South Pacific Region}

This article offers some background on a current issue in Pacific regionalism with reference to the problems of the University of the South Pacific (USP). The USP was established in 1968 for the twelve English speaking Pacific Island states located south of the equator (Samoa, Fiji, Tonga, Kiribati, Nauru, Niue, Solomon Islands, Tokelau, Tuvalu, Vanuatu, and Cook Islands), and later included the northern Pacific Marshall Islands, (Crocombe M, 1988: 29). Its establishment was coordinated and funded by the joint efforts of the United Nations, Australian, British and New Zealand governments (Aikman, 1988 p. 35-38). Fiji was chosen as its location when New Zealand offered suitable premises at the former New Zealand air base at Laucala Bay in Suva. The rationale for its establishment was to reduce the dependence of the new states on expatriate teachers and administrators and to build a spirit of Pacific Island regional identity.

When USP was established, decolonisation was underway in the Pacific. The decolonisation of the Pacific Island states began in 1962 with Samoa the first to achieve independence. This was followed by Nauru (1968), Fiji (1970), Tonga (1970), Papua New Guinea (1975) and, Solomon Islands (1978), Tuvalu (1978), Kiribati (1979), the Federated States of Micronesia (1986), Marshall Islands (1986) and Palau (1994). The other Pacific Island states were granted self-governance but still remained in 'free association' relations with the former administrative powers such as that of the Cook Islands and Niue with New Zealand. New Caledonia, Tahiti, Wallis and Futuna and French Polynesia are overseas territories of France, while American Samoa, Northern Mariana Islands and Guam remain territories of the United States of America. Tokelau is a dependent territory of New Zealand.

During this period most Pacific Island governments had only recently established schools offering more than elementary levels. In the 1960s a few people who had achieved well in school were sent overseas for senior secondary schooling and higher education. Only the more populous countries, Fiji and Papua New Guinea had specialised education in fields such as medicine. Large South Pacific Island states such as Papua New Guinea, Fiji and Samoa were also able to establish national teacher's colleges alongside the existing theological colleges. Small South Pacific Island states such as Tokelau, Niue and the Cook Islands either struggled or were not able to establish post-secondary education institutions due to their small size and limited resources (Crocombe R, 1994:26 - 27).

\section{Early Initiatives in Higher Education}

Papua New Guinea led the way when the Administrative College (now the PNG Institute of Public Administration) was established in 1963 (Pacific Precinct, n.d). Two years later, the University of Papua New Guinea (UPNG) was founded in 1965 by the Australian colonial administration making it the first official university in the South Pacific region (Weeks, 1991:3). Since then, Papua New Guinea's large population and resources have allowed the island state to establish at least three national institutions of higher education since 1965, as well as two operated by churches. With the establishment of UPNG, the former colonial powers acknowledged the need for post-secondary education in the region, and decided in 1966 to explore the idea of an institution of higher education for the South Pacific region. This is what led to the establishment of USP in 1968 (Luteru 1991:78).

As most small Pacific Island states could not afford to offer senior secondary levels for university entrance, and because few of their people qualified for training overseas, the leaders of Pacific Island states supported the concept of a regional university (Baba, 1991). For this reason USP immediately established pre-degree bridging programmes to provide university entrance certificates leading to diploma and degree level programmes. 


\section{Meeting early ends for higher education}

Until the 1980s the USP satisfied most of the higher educational needs of its member countries, but in some of the larger island states there was a growing need for local higher education, to train secondary school teachers, nurses, technicians, and administrators. The cost of exporting all this training was expensive and also posed a risk of brain drain with graduates in some fields such as medicine, often opting not to return home for work when overseas opportunities at higher salaries existed (Docquier, 2014). There was also a need for more emphasis on national culture in teacher training, as exemplified in 1975 by the establishment of the Atenisi Institute in Tonga, a brave effort to establish a post-secondary college without support from the state or aid donors.

The desire of individual Pacific Island states to establish their own national institutions of higher education were constrained by the on-going commitment of the former colonial powers and USP donors to channel resources to one institution for the whole region or to fund scholarship in the countries of the donors. This limited the government's economic capacity to redirect the majority of aid-funded scholarship toward building and sustaining their own national higher education and postsecondary training institutions (Crocombe \& Meleisea, 1988 p. 34). It was more cost-effective and convenient for donors to fund one institution for the region compared to funding separate national institutions. The all-the-eggs-in-one-basket approach by aid donors made sense at the time of USP establishment when larger island states such as Samoa, Vanuatu and Solomon Islands had only small numbers of students graduating from secondary schools with university entrance qualifications.

\section{USP's in-country presence}

Concern began to be voiced about the disproportionate benefits USP offered to Fiji in the 1980s. These benefits included numbers of enrolments and consumers, taxation, and employment opportunities. Early critics were Ron Crocombe who was Professor of Pacific Studies at USP, and Professor Albert Wendt, who also taught at USP for many years, commented on Fiji's disproportional benefits from USP:

'Our governments and donor governments should ask themselves if they are still willing to finance an institution which, I believe, is Fiji's national university' (Crocombe R, 1994 p. 127.)

To spread the benefits in the early 1980s, USP and its aid donors established university extension centres in each of the member countries and later decentralised its Faculty of Law to Vanuatu, its Faculty of Agriculture to Samoa, and had established an Atoll Research Unit in Kiribati. The extension centres (now described as 'campuses' of USP) were originally set up to deliver continuing education and programmes of study by correspondence, once using a satellite to broadcast tutorials, later developed to online learning modes as most member countries obtained internet connectivity computers and other communication technology. The extension centres did not equally satisfy all the member countries higher educational needs as they did not offer the full facilities to study for a degree in-country. This came at a cost for students or their governments outside Fiji because students enrolled by distance education are usually required to spend part of their learning time at the main Laucala Campus in Fiji for varying periods of time during their degree studies (Tuingariki \& Short, 1991 p. 113). In the case of Samoa, Fiji and Solomon Islands, USP's in-country facilities have an aidsubsidised competitive edge over national universities.

\section{National needs and aspirations for higher education}

By the 1980s and the 1990s there was a rising demand to train professional's in-country, especially in fields such as education, medicine, business, administration and technology. Today the majority of small Pacific Island states are still dependent on aid-funded scholarships to USP, or to universities in Papua New Guinea, New Zealand and Australia for higher education. Over the past thirty years or so scholarships to many other English-speaking countries and to China have become available. 
As shown in Table 1, only the first six countries ranked by population size might reasonably be able to support a small national university tailored to their national human resource needs. However with the exception of Tuvalu and Nauru, four of the remaining six countries are in free association with the country that formerly administered them and have access to education in those countries. Fiji, Samoa and Solomon Islands have already established national universities and would welcome students from other Pacific Island countries such as Tonga Nauru, Tuvalu and Kiribati, if aid-funded scholarships were provided.

Table 1: Population of USP Member States

\begin{tabular}{|l|l|l|l|}
\hline Size rank & Country & Population & Date \\
\hline 1 & Fiji & 896,445 & 2015 \\
\hline 2 & Solomon Islands & 667,044 & 2015 \\
\hline 3 & Vanuatu & 304,500 & 2015 \\
\hline 4 & Samoa & 199,052 & 2016 \\
\hline 5 & Kiribati & 120,100 & 2015 \\
\hline 6 & Tonga & 100,651 & 2015 \\
\hline 7 & Marshall Islands (USA) & 55,500 & 2015 \\
\hline 8 & Cook Islands (NZ) & 18,100 & 2015 \\
\hline 9 & Tuvalu & 10,640 & 2015 \\
\hline 10 & Nauru & 10,084 & 2015 \\
\hline 11 & Niue (NZ) & 1,611 & 2013 \\
\hline 12 & Tokelau (NZ) & 1,499 & 2015 \\
\hline
\end{tabular}

Source: https://en.wikipedia.org/wiki/List of Oceanian countries by population

\section{Funding of USP}

The World Bank (2000 p. 50) taskforce argues that 'higher education institutions can thrive only if their funding levels are adequate, stable and secure in the long term'. The USP is securely funded with Australia and New Zealand contributing directly to its operational budget. In addition, Australia and New Zealand award scholarships and special grants channelled at USP. Each of the twelve member countries as collective owners of USP also provide direct funding to the regional university.

Overall USP has an annual budget of approximately $\$ 257$ million tala (source:

https://www.usp.ac.fi/index.php?id=109). The USP also receives revenue from tuitions from selffunded students (predominantly Fijian nationals), leasing out its venues and sales of its publications. In comparison the National University of Samoa (NUS) annual budget is approximately \$20 million tala and is heavily reliant on tuition fees to keep the institution afloat (Groves, 2019). The UPNG annual budget is approximately $\$ 56$ million tala and is also heavily reliant on tuitions for additional funding (PNG Education News, 2019). This means that USP is the highest funded university in the Pacific region aside from the US funded University of Guam and those funded by France in New Caledonia and French Polynesia.

Although USP is securely funded, there have not been equitable benefits for all member countries, as pointed out many years ago by Crocombe and Meleisea, (1988 p. $346-63)$. This is because Pacific Island countries have different funding needs according to their size, resources, and education and training systems. For instance, in the early 1990s, island states such as Tuvalu had to run short courses for adults on several of its isolated islands as it was cheaper to send training staff out than to bring students in (Crocombe R, 1994 p. 25). However, for a larger Pacific Island like Samoa, it is cheaper to have students attend a national institution than it is to send the students out to USP or New Zealand. 


\section{Emergence of National Institutions}

In 1983, the Government of Samoa announced its intention to establish a national institution of higher education and on February 14th 1984, the NUS was established with the University Preparatory Year programme mirroring that of USP (Groves, 2019). The founding of national institutions in the Solomon Islands, as well as outside the USP region in French Polynesia, New Caledonia and Guam soon followed. These new institutions began to offer secondary teacher training, general, technical, and advanced study in various fields such as humanities, science, business, health and trades.

The hopes of the other Pacific Island states to follow suit remain constrained by the lack of support from the development partners. At the national level major donors such as Australia and New Zealand, place the greatest emphasis on health and basic education, overlooking the need to assist higher education services towards better quality training of teachers, health workers and sector administrators.

By the 2000s towards the present day, the economies and populations of Fiji, Samoa and Solomon Islands have grown considerably allowing them fund and sustain national institutions of higher education via government subsidies and aid apportioned to the education sector as a whole in addition to tuition fees and other revenues. USP remains the best option for Tuvalu, Nauru, Tokelau and Kiribati, but these countries could also send students to national Pacific Island universities if scholarships were made available. Table 2 below shows a list of Pacific Island universities and higher education institutions in a chronological order:

Table 2: Pacific Islands Universities Timeline

\begin{tabular}{|l|l|}
\hline Institution & Year Established \\
\hline Institute of Public Administration & 1963 \\
\hline University of Papua New Guinea & 1965 \\
\hline $\begin{array}{l}\text { Papua New Guinea University of Natural Resources } \\
\text { and Environment }\end{array}$ & 1965 \\
\hline Papua New Guinea University of Technology & 1965 \\
\hline University of the South Pacific & 1968 \\
\hline Atenisi Institute (Tonga) & 1975 \\
\hline National University of Samoa & 1984 \\
\hline Pacific Adventist University (PNG) & 1984 \\
\hline $\begin{array}{l}\text { Solomon Islands National University (formerly the } \\
\text { Solomon Islands College of Higher Education) }\end{array}$ & 1984 \\
\hline University of French Polynesia & 1987 \\
\hline University of Goroka (PNG) & 1997 \\
\hline University of New Caledonia & 1999 \\
\hline
\end{tabular}




\begin{tabular}{|l|l|}
\hline University of Fiji & 2004 \\
\hline Fiji National University & 2010 \\
\hline
\end{tabular}

\section{Problems of donor support for regionalism in higher education}

Regionalism was once a high ideal but one that has gradually withered with the demise of a regional airline and shipping service and (so far unsuccessful) resistance by Fiji to Australia and New Zealand having a presence in the Pacific Forum. The headquarters of the Forum and USP sit, often uncomfortably, in Fiji, which has had a series of military coups since 1987 and considerable political instability between coups. For many years now most of USPs staff at all levels have been Fijian nationals. In 2020 it is in turmoil over allegations of mismanagement, Fiji government interference, and, so far, the member states appear powerless to resolve the situation.

It may be a time to rethink the role of USP as a more specialised regional institution. Perhaps it might become a regional institution for post-graduate studies and research, allowing more aid-sponsored and government investment in the under-graduate programmes of national universities and Pacific inter-country student exchanges. There could be stronger partnerships, supported with development assistance funding, with New Zealand and Australian universities to develop accredited professional programmes and build capacity in technical and vocational education. There are countless opportunities that can be achieved at a larger scale if donor assistance can be disbursed throughout the regions national institutions. Maybe it is time for a change. Let us ask ourselves, do we still believe that the Pacific Islands need a regional university?

\section{Acknowledgement}

This article draws on the second chapter of my 2019 NUS Master's thesis in Development Studies titled 'The Five Tala University: Higher Education in Developing Countries - A Case Study of the National University of Samoa'. I thank Associate Professor Penelope Schoeffel for her editorial assistance.

\section{References}

Aikman, C.M. 1988. "Establishment: 1968-74." Pp.35 in Pacific Universities: Achievements, Problems and Prospects, eds R. G. Crocombe, and M. Meleisea. Suva: Institute of Pacific Studies, University of the South Pacific.

Crocombe, M. 1988. "Satellites and Centres." Pp.119 in Pacific Universities: Achievements, Problems and Prospects' eds R. G. Crocombe and M. Meleisea. Suva: Institute of Pacific Studies, University of the South Pacific.

Crocombe, M.T., and Crocombe, R.G.1994. Post-Secondary Education in the South Pacific: Development in the Small States of the Commonwealth Series. Commonwealth Secretariat: London.

Docquier, F. 2014, "The brain drain from developing countries: The brain drain produces many more losers than winners in developing countries." IZA World of Labor 2014: 1- 10. doi: $10.15185 /$ izawol.31

Groves, E.C. 2019. "The Five Tala University: Higher Education in Developing Countries - A Case Study of the National University of Samoa." Unpublished Master's Thesis, Apia, Samoa: National University of Samoa.

Luteru, P.H. 1991. "The Impact of Foreign Aid on Pacific Mores, Ideas and Traditions" Pp. 5-87 in Explorations in Higher Education: A South Pacific critique, eds D.R. Jones, V.L. Meek and J. Weeks: The Centre for the Study of Higher Education, University of Melbourne.

Pacific Leadership and Governance Precinct. 2020. History of the Precinct. http://pacificprecinct.org/about-us/history-of-leadership/ (accessed 30 May 2020). 
PNG Education News.2019. "UPNG to Get K44mil for Operations, Maintenance." PNG Education News, https://edu.pngfacts.com/education-news/upng-to-get-k44mil-for-operationsmaintenance (accessed 27 June 2020).

Pacific Islands Universities Research Network (PIURN). 2019. Member Universities. https://piurn.org/member-universities-pacific-island-universities-research-network/ (accessed 06 May 2020).

Tuingariki \& Short. C, 1991. "Higher Education and the needs of Small Islands in the South Pacific Region." Pp. 103-112 in Explorations in Higher Education: A South Pacific critique, eds D.R. Jones, V.L. Meek and J.Weeks. The Centre for the Study of Higher Education, University of Melbourne.

Baba T.L, 1991. "Education in the Small Island States of the South Pacific: The Changing Role of the School and its implications for Higher Education" in Explorations in Higher Education: A South Pacific critique, eds D.R. Jones, V.L. Meek and J.Weeks. The Centre for the Study of Higher Education, University of Melbourne.

Wikipedia.2018. List of sovereign states and dependent territories in Oceania, Wikipedia the Free Encyclopedia.https://en.wikipedia.org/wiki/List of sovereign states and dependent territ ories in Oceania (accessed 09 February 2019).

Wikipedia, n.d. Atenisi Institute, Wikipedia.org. https://en.wikipedia.org/wiki/\%CA\%BBAtenisi Institute (accessed 10 March 2019).

World Bank 2000. Higher Education in Developing Countries. The International Bank for Reconstruction and Development, The World Bank. 